Alma Mater Studiorum - Università di Bologna DEPARTMENT OF ECONOMICS

\title{
Inequality and Democracy
}

\author{
Anna Soci
}

Quaderni - Working Paper DSE N¹131

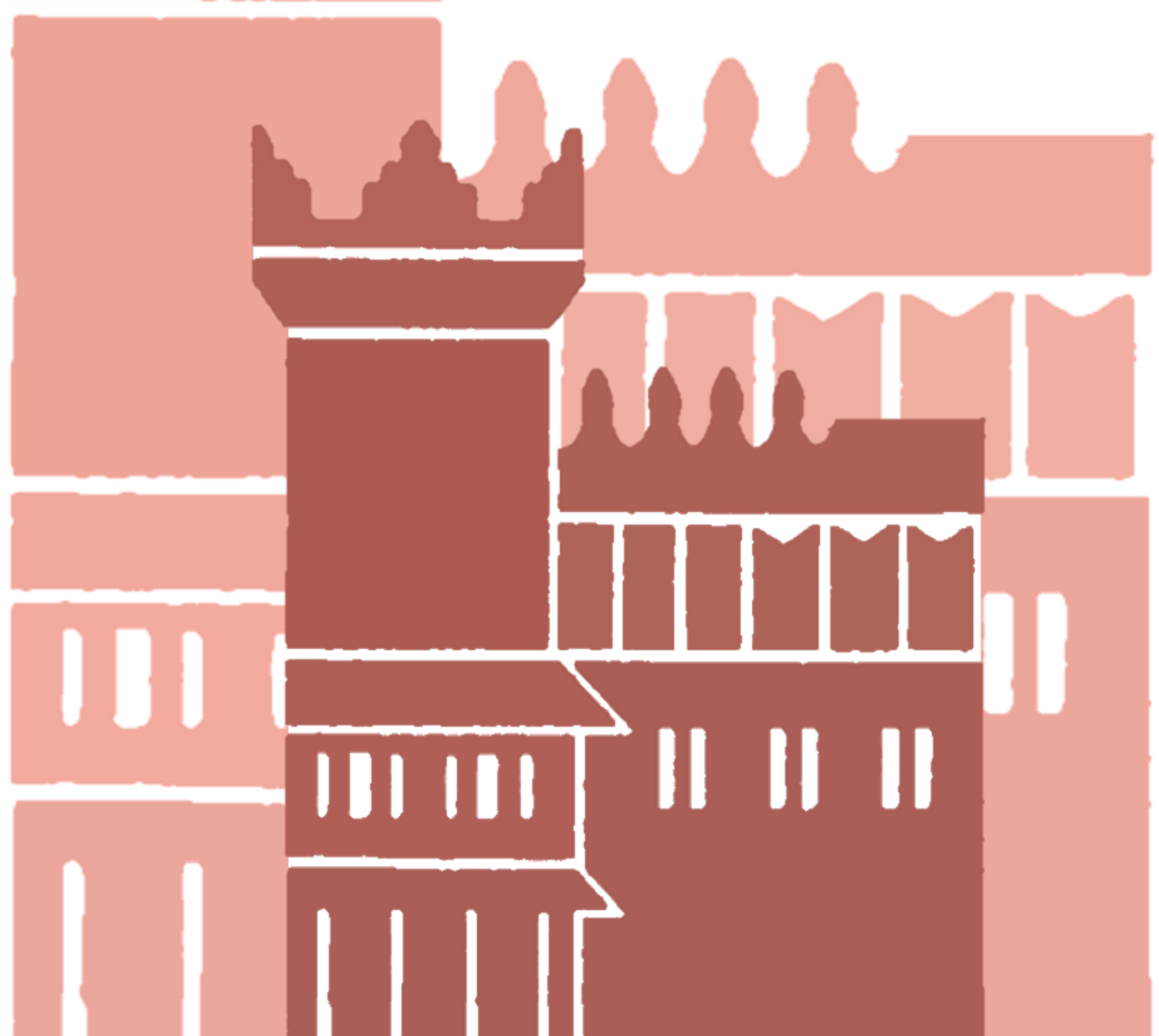




\title{
Inequality and Democracy
}

\author{
Anna Soci*
}

\begin{abstract}
The paper is about the political consequences of increasing economic inequality in Western economies. Political theorists have often stressed that democracy is in troubles when its population is not broadly uniform in income and wealth because unequal economic resources can easily translate into a surplus of political resources in the hands of the few. The connections between economic inequality and democracy, however, are not easy to detect and the body of literature is not so large to provide robust assessments of their complex relationship. The aim of this paper is to review the links between the two and to offer some hints on the political relevance of the inequality consequences, if any, on democracy.
\end{abstract}

Keywords: Inequality; Social consequences; Political consequences; Democracy change

JEL classification: A13; D6;

*Corresponding author: Department of Economics, University of Bologna, Strada Maggiore 45, 40125 Bologna, Italy; anna.soci@unibo.it 


\section{NON-TECHNICAL SUMMARY}

This paper is a substantial re-modulation and extension of Ch.5 "Inequality and Democracy" written by the author and part of the book "Inequality: a short history" co-authored with Michele Alacevich [Brookings Institution, Washington, 2018 and Agenda Publisher, London, 2018].

Starting from the statement that economic and social inequality is not expected to convert necessarily into political inequality in a democracy, the interesting question is what happens when it does. The topic of this paper is a broad inquiry into the effects of inequality on the economic and social environment as well as into the effects of a worsened economic and social context on the political environment, still within a democratic framework.

While theorizing leads to a positive correlation between inequality and deterioration of democracy, the empirical results show that the validation of the transmission of socio-economic inequality into political inequality is still scant, and the main cause is due to the rudimentary state of the measurement of political influence, and to the difficulty of measuring democracy and its quality. 


\section{INTRODUCTION}

It is sad to admit that only recently the research in Economics has become interested in the personal distribution of economic resources, topic that has never been central in the economic thought of whatever period and orientation. One of the reasons for a renewed interest - if not the main one is that economically developed countries are now experiencing an alarming degree of inequality. In the twenty-first century prolonged unemployment, declining labour-share, the increasing accumulation of wealth by the few coexisting with stagnant incomes for the rest, and a steeper social ladder, are the main factors that have brought the personal distribution of income to centre stage. Today economic inequality is at the forefront of political debate, arguably because social movements have emerged that forced all of us to turn our attention to this issue.

This paper looks exclusively at the relationship between economic inequality and democracy. I maintain that (a certain degree of) inequality damages growth, worsens social cleavages and eventually deteriorates the quality of the democratic setting hampering a full enjoying of democracy by low-income people. 


\section{TWO QUESTIONS}

The previous sentence contains two separate issues: one is the detrimental effect of inequality on the economic and social environment and one is the effect of a worsened economic and social context on the political environment still within a democratic framework. The first aspect mainly relates to growth and its relevant social impact. It is undeniable that growth is a sort of pre-requisite to an overall improvement in living conditions, but growth can both smooth and intensify differences whether it benefits the entire population or just one part of it respectively. The second aspect concerns the reverberation of the effects of economic inequality on the democratic context. The specific question is whether people can be politically equal if they are socially unequal.

\subsection{FIRST QUESTION}

\section{Inequality: economic and social consequences}

The interest of economists in assessing the relation between inequality and growth has been mainly to establish whether tackling inequality might make societies wealthier.

However, still today the answer to the question "does inequality slow growth" is only tentative, since the main theoretical forces shaping the relationship may be conflicting. Two are the basic arguments that many possible explanations can flow into: "incentive" or "opportunity". Inequality affects growth positively by providing incentives to work, to invest and take risks, and/or inequality affects growth negatively by subtracting opportunities 
to the poor and low-income people. Consequences of inequality for growth will depend on which of these forces prevails.

In the first view - the traditional one - the main concern is the size of the pie and the priority of the individual. The traditional view maintained that supporting the rich would increase aggregate savings, which in turn would increase investment with benefits for the growth of GDP. So far so good. However, in order to become "investment" savings has to be transferred to firms through the financial and/or the banking system. Unfortunately, nowadays both seem to have a sustained degree of inertia towards theirs preeminent function and both prefer to turn into a more lucrative "financialization". Moreover, and quite independently on savings, investment has to be an attractive economic option, and Keynes taught us since that investment depends first and foremost on demand-expectations rather than on fund-availability. Thus, for more than one reason a mismatch between the supply (savings) and the demand (investment) of loanable funds can occur, and the process of capital accumulation can be relented or even stopped. A serious challenge to growth may come into action depending on the structure of the economy - whether the main sectors are high-tech or not- and on the size of the firms - whether they are big enough and able to finance themselves in the international markets. In other words, there is no automaticity between the existence of even a big amount of saving and the realization of investment, as the recent experience in the majority of Western economies confirms.

Again, in the traditional view the economic perspective holds that in a highly egalitarian framework incentives thin out, and the total amount of 
productive effort in the economy decreases making all - including the poor worse off than in a less egalitarian context. According to this view, in a market economy inequality reflects the true abilities or inabilities of people and the "natural" differences among them, provided (at least in the democratic version of this line of thought) that they are given equality of opportunity by the state. This position had its manifesto in the 1953 Milton Friedman's article, with his assessment that "Individual choice through the market can greatly modify the effect on the personal distribution of income both of circumstances outside the control of individuals concerned and of collective actions designed to affect the distribution of income," such as taxation and subsidies. ${ }^{1}$ Still in the traditional view, the perspective holds that taxes and transfers implemented according to any "median voter" theory slow down the pace of growth because of the distortion brought by redistribution. According to this so- called theorem, ${ }^{2}$ in a democratic system the combination of taxes and transfers will be the one preferred by the voter who stays exactly in the middle of the distribution: the voter who has the median income. Since the empirical distributions in all advanced economies exhibit a median income lower than the mean, the higher the economic inequality the higher the combination of taxes and transfers in the preferences of the median voter should be.

\footnotetext{
${ }^{1}$ Milton Friedman, "Choice, Chance and the Personal Distribution of Income," Journal of Political Economy 61, no. 4, August 1953, 277-90, at pp. 277-78.

${ }^{2}$ This evergreen theorem was originally introduced in Duncan Black, "On the Rationale of Group Decision-making," Journal of Political Economy 56, no. 1, 1948, 23-34, and later developed in Kevin W. S. Roberts, "Voting over Income Tax Schedule," Journal of Public Economics 8, no. 3, 1977, 329-40, and Allan H. Meltzer and Scott F. Richard, "A Rational Theory of the Size of Government," Journal of Political Economy 89, 1981, 914-27.
} 
The endogenous growth theory of the 1990s contributed theoretically to alter this traditional line of thought. Hinging on the consideration that human capital is as important as (if not more important than) real capital, it brought education to the forefront. If education becomes pivotal for growth, and if surging inequality means shrinking opportunities for poor or lowincome people, a transformation not for the better will occur resulting in under-investment in human capital. Informational asymmetries and credit constraints will take place. When credit-constraint binds people without tangible assets in their borrowing capacity and schooling becomes too expensive for low-income families, investment in human capital would decline, and growth would seriously be challenged in a self-reinforcing mechanism through the lock-in effect. If education becomes financially unaffordable, it also becomes less relevant for the low-educated ones, who often are the same families, and if a society is divided in terms of resources, the more reluctant the rich are to spend money on society.

Besides the impact on human capital accumulation, other reasons exist for inequality ceasing to be - if possible - "useful" for growth. Simply put, let us suppose that the falling wages of the "working poor" - which lead to a shrink in consumption - combine with the increasing salaries of the "working rich", the top managers who are not themselves owners of the capital but work for a capitalist who is usually hidden from the public eye. Short-term rather than long-term profit is the likely goal of these managers since their income would reflect the stock-market value of the firm. Short-term investment - which is generally a financial kind of investment - would replace the long-term one, investment in real capacity. Both outcomes - shrink in 
consumption and stagnation if not reduction in investment - would eventually lead to a contraction of the aggregate demand and to pessimism in expectations on the firms' side, discouraging even more their interest in investment and increasing instead their drive towards financial speculation. Thus, the split between the enrichment of the few and the interest of the many eventually sabotages growth itself. ${ }^{3}$

Which mechanism has received validation from data? Ambiguously, the second one. The answer to the question "does inequality within a country slow its growth?" is likely to be positive ${ }^{4}$, though 1 ) the direction of causality appears not so easy to ascertain, ${ }^{5} 2$ ) the relation might be between inequality and the duration of growth-spells, ${ }^{6}$ and 3) net inequality should to be checked against growth in order to avoid the effect of re-distribution. ${ }^{7}$ Moreover, a "meta-analysis" shows that the estimation methodology, quality of data and sampling do have a substantial role in directing results. ${ }^{8}$ What matters more, the co-existence of opposite theoretical explanations suggests the possible presence of non-linearity in the relationship, which implies that inequality might damage the economy after it reaches some "tipping point" ${ }^{\prime}$. This possibility was already found in Barro [2000] - though in a context of

\footnotetext{
${ }^{3}$ For a complete account, see Stiglitz [2012]

${ }^{4}$ Cingano [2014] provides wide evidence of the results in the main empirical literature: see his Table A2-1

${ }^{5}$ Bertola [1993], Alesina and Rodrik [1994], Persson and Tabellini [1994], Perotti [1996], Alesina and Perotti [1996], Benabou [1996]

${ }^{6}$ Berg and Ostry [2011]. The growth-spell is the interval starting with a growth up-break and ending with a down-break.

${ }^{7}$ Ostry et al. [2014]

${ }^{8}$ De Dominicis et al. [2008], and also Cingano [2014], at pp. 12-13

${ }^{9}$ Fukuyama attributes this non-linearity directly to political reaction: "there is a tipping point at which social stratification becomes entrenched producing political polarization and distinctive patterns of behaviour between rich and poor". Fukuyama [2011] at p. 85
} 
development à-la-Kuznetz - and was proposed theoretically by Benhabib [2003] who, not surprisingly, linked together the two theories: increases in low levels of inequality can provide incentives to be more productive, but increases from higher levels of inequality would likely lead to rent-seeking behaviours. Thus, also initial inequality levels do matter. In other words, "the relationship between equality and economic performance is likely to be contingent rather than fixed, depending on the deeper causes of inequality and many mediating factors", as Rodrik [2014] recently commented. We will be back on this.

Though this non-linearity does not seem to be proved when linear relations are tested (i.e., the effect of an increase in some Gini points is the same at different levels of the Gini coefficient ${ }^{10}$ ), it is on the contrary confirmed when a non-linear structure is used. In an important methodological paper, Banerjee and Duflo [2003] provide a "warning against the automatic use of linear models in settings where the theory does not necessarily predict a linear or even a monotonic relationship", and add that "data does seem inconsistent with a linear structure" [of the relationship between inequality and growth] $]^{11}$. On the same line, Grigoli and Roberts [2016] find pervasive evidence of nonlinearities and find in addition that "the slope of the relationship between inequality and economic development from positive turns negative at a net Gini of about 27 percent, indicating that the inequality overhang occurs even at relatively low levels of income inequality". ${ }^{12}$ Moreover, is it only a problem of levels - a low or high value of

\footnotetext{
${ }^{10}$ Again Cingano [2014] at p. 19

11 Banerjee and Duflo [2003] at p. 296

${ }^{12}$ Grigoli and Roberts [2016] at p. 3
} 
the Gini - and/or of the rate of increase in these levels? It appears that it is not. Drawing on harmonised data covering the OECD countries over the past 30 years, Cingano [2014] shows that it is the gap between low- and lowermiddle income households (the bottom 40\%) and the rest of the population to be relevant. It is the relative inequality in the low portion of the distribution that is harmful to growth. Top relative inequality has less, if any, relevance. Why?

The human capital accumulation story comes on stage again. Whether the rich be just a little or very far ahead from the average economic resources does not matter at all for their investment in education (and what follows from that, lato sensu). If the low-income people are below - and far below the average, it will be probably difficult or perhaps impossible for them to do the same. Inequality reduces the full achievement of growth reachable in a society since it reduces the contribution to human capital from almost the bottom half of the distribution, lowering investment opportunities of the lower segments of the population. The research specifically aimed at evaluating education inequality had already found that it is this element more than income inequality to be associated with lower investment rates and, consequently, lower income growth. ${ }^{13}$ However, educational inequality is just one of the many unequally distributed opportunities (for instance, access to health care or other wealth-enhancing service, or access to the labour market for good and regularly paid jobs) whose progressive shrinking is defined by Milanovic [2016] as a true structural change. This ongoing societal polarization entails that the disadvantages suffered by one generation would shift ahead

\footnotetext{
${ }^{13}$ Castelid and Domenech [2002]
} 
to the next generation if suitable policies for remedying were not implemented. Sustained, prolonged and unleashed inequality enhances the intergenerational transmission of characteristics - social or economic - and makes them less escapable.

This intergenerational - social and economic - (im)mobility is actually what emerges as a featuring trait of our times. In a cross-country comparison (initially Sweden, Norway, Denmark, Finland, Germany, France, Canada, UK, US, then enlarged to several other countries) Corak [2006] and [2013] has tested the relationship between inequality and inter-generational mobility. He found what Krueger - economist and ex-Chairman of the Council of Economic Advisers - imaginatively labeled as the "Great Gatsby curve" (Figure 1) just recalling Gatsby's difficulties in climbing the social ladder in spite of his money. ${ }^{14}$ This relationship is positive: increasing intergenerational income elasticity (IGE) and increasing inequality go together. An increasing IGE represents a society with a lesser mobility since a value of 0.8 , for instance, means that if one father makes $100 \%$ more than another the son of the high income father will earn $80 \%$ more than the son of the relatively lower income father. In other words, the closer the index is to 1 the more similar are the incomes across generations. "The Great Gatsby Curve is not a causal relationship but it is too glib to dismiss it by saying correlation does not imply causation" (Corak [2013] at p.85). In the remaining of the article, Corak reviews the many pieces of theory that can suit the Great Gatsby Curve, concluding that inequality affects mobility because it shapes opportunities

\footnotetext{
${ }^{14}$ A. B. Krueger, "The Rise and Consequences of Inequality in the United States," speech given at the Center for American Progress on January $12^{\text {th }}, 2012$, where he acknowledges the earlier work by Corak.
} 
and heightens the income consequences of innate differences between individuals.

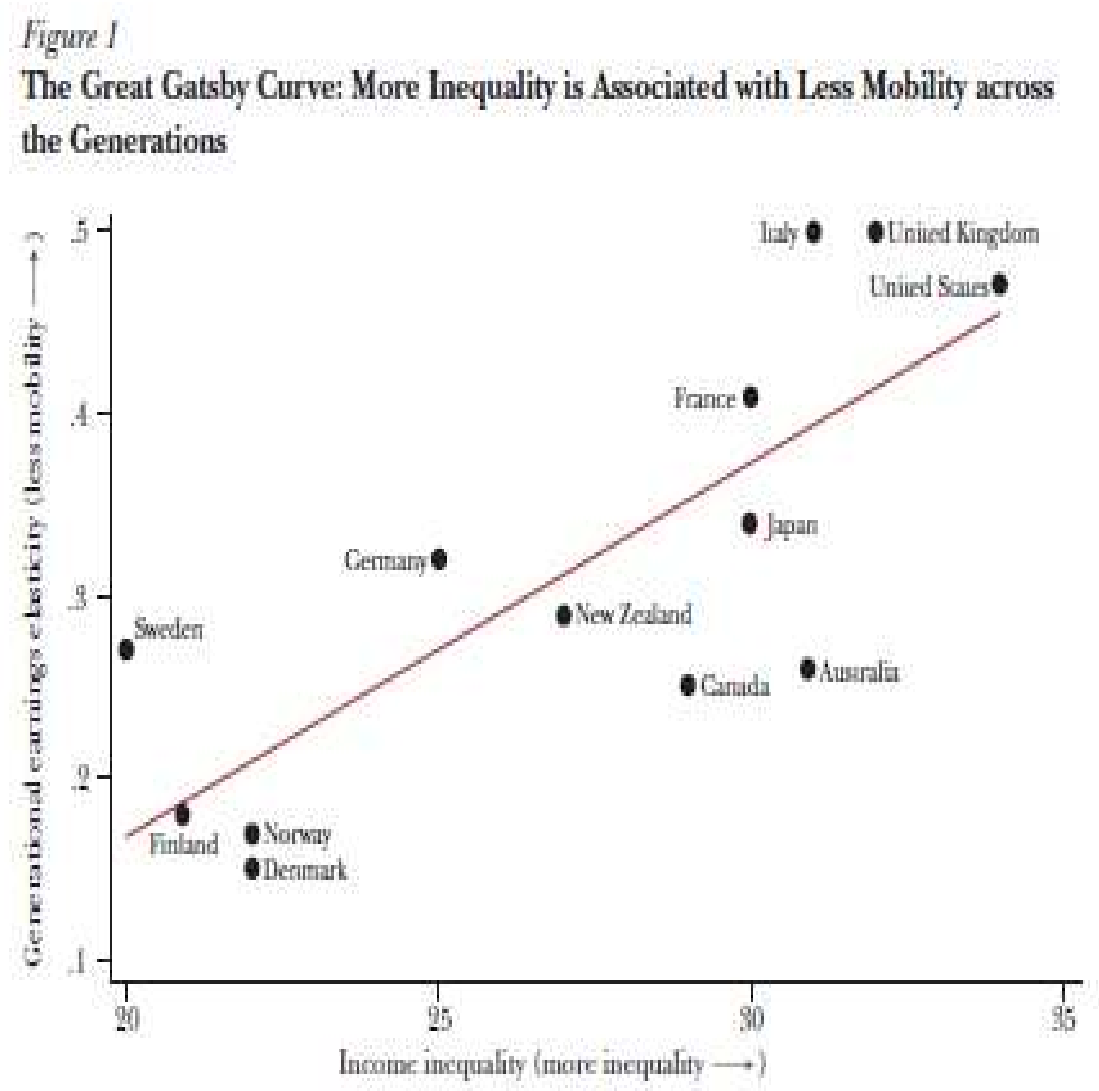

Senc: Corak (9013) and OECD.

Nones lncome inequality is measured as the Guni coefficient, uning disposable houschold income for about 1985 as provided by the OECD. Intergeneraitonal conomic mobility is mensured as the dasticity between paternal carnings and a son's adtult camings, using data on a cohort of dildren born, roughty speaking, during the carly to mid 1960 s and measuring their adult -outcomes in the mid to late $1990 \mathrm{~s}$.

Jäntti and others [2006] paralleled ${ }^{15}$ this outcome adding a new important perspective. Considering almost the same restricted set of countries as of Corak's [2006], they found that although all countries exhibit substantial earnings persistence across generations, the persistence is not uniformly distributed (Figure 2). Most of the difference is confined to the tails

${ }^{15}$ Corak's main results go back to his [2006] paper 
of income distribution showing a great low-income and high-income persistence: both the rich and the poor are "trapped" (with very different fortunes)! The middle is still mobile in the US and this is probably what has sustained until now the narrative of the "American dream".

Figure 2. Intergenerational mobility across the earnings distribution

Probability of the son of being in the same earnings quintile as his father

\begin{tabular}{lcccccc}
\hline & Denmark & Finland & Norway & Sweden & United & United States \\
\cline { 2 - 6 } $1^{\text {st }}$ Quintile & 0,25 & 0,28 & 0,28 & 0,26 & 0,30 & 0,42 \\
$2^{\text {nd }}$ Quintile & 0,25 & 0,22 & 0,24 & 0,23 & 0,23 & 0,28 \\
$3^{\text {rd }}$ Quintile & 0,22 & 0,22 & 0,22 & 0,22 & 0,19 & 0,26 \\
$4^{\text {th }}$ Quintile & 0,22 & 0,23 & 0,22 & 0,22 & 0,25 & 0,25 \\
$5^{\text {th }}$ Quintile & 0,36 & 0,35 & 0,35 & 0,37 & 0,35 & 0,36 \\
\hline
\end{tabular}

Source: Based on the diagonal of the transition matrices estimated by Jäntti et al. (2006).

Just in the US, however, the situation of "the middles" is not the same any longer. The hollow-out of the central portion of the income distribution contributed to the wide distress -and angriness - of a substantial (numerically and ideologically) part of the population, though this phenomenon is not confined to the US only. The sociological and political literature is now documenting in different form and with different accents this worrying phenomenon. ${ }^{16}$ Here again two are the problems. The first lies in the reasons for the discomfort with the social and political life - at issue here - which highly reverberates on essential constituency of democracy such as trust, for instance. ${ }^{17}$ The second is the nature and relevance of who are the main actors in this social and political conflict, thing that is likely to determine the

${ }^{16}$ Reeves [2017], Williams [2017], Shapiro [2017]

${ }^{17}$ Barone and Mocetti [2014] find a significant and negative effect of inequality on generalized trust, and Gould and Hijzen [2016] document the lowering in trust towards the others and the institutions both in the US and in several advanced countries. 
outcome, i.e. the future organization and governance of a society. I will discuss this latter issue in a forthcoming work.

There are of course unexplained parts of the transmission mechanisms from one generation to the next one concerning family background or the social surrounding environment where beliefs and values are shaped. In this framework, and as for Corak's Great Gatsby Curve, another striking "correlation" has emerged: that one between economic inequality and social disadvantage. A 2009 study by Richard G. Wilkinson and Kate Pickett provides this evidence in a wide sample of rich and industrialized countries. The interdeciles ratio P80/P20 - as the measure of inequality - is plotted against a composite index of level of trust, mental illness, life expectancy, infant mortality, obesity, children educational performance, teenage birth, homicides, imprisonment rates, and social mobility. Whether social problems had been caused by material life conditions, the more affluent countries should have performed better than the less affluent. No correlation along this line emerges (Figure 3). On the contrary, the correlation emerges unambiguously as positive once the variable plotted against the social composite index is the measure of inequality (Figure 4). The message is strong: the more unequal rich countries among the twenty-three sampled do worse according to almost every quality of life indicator. 
Figure 3: Health and social problems are only weakly related to national average income among rich countries

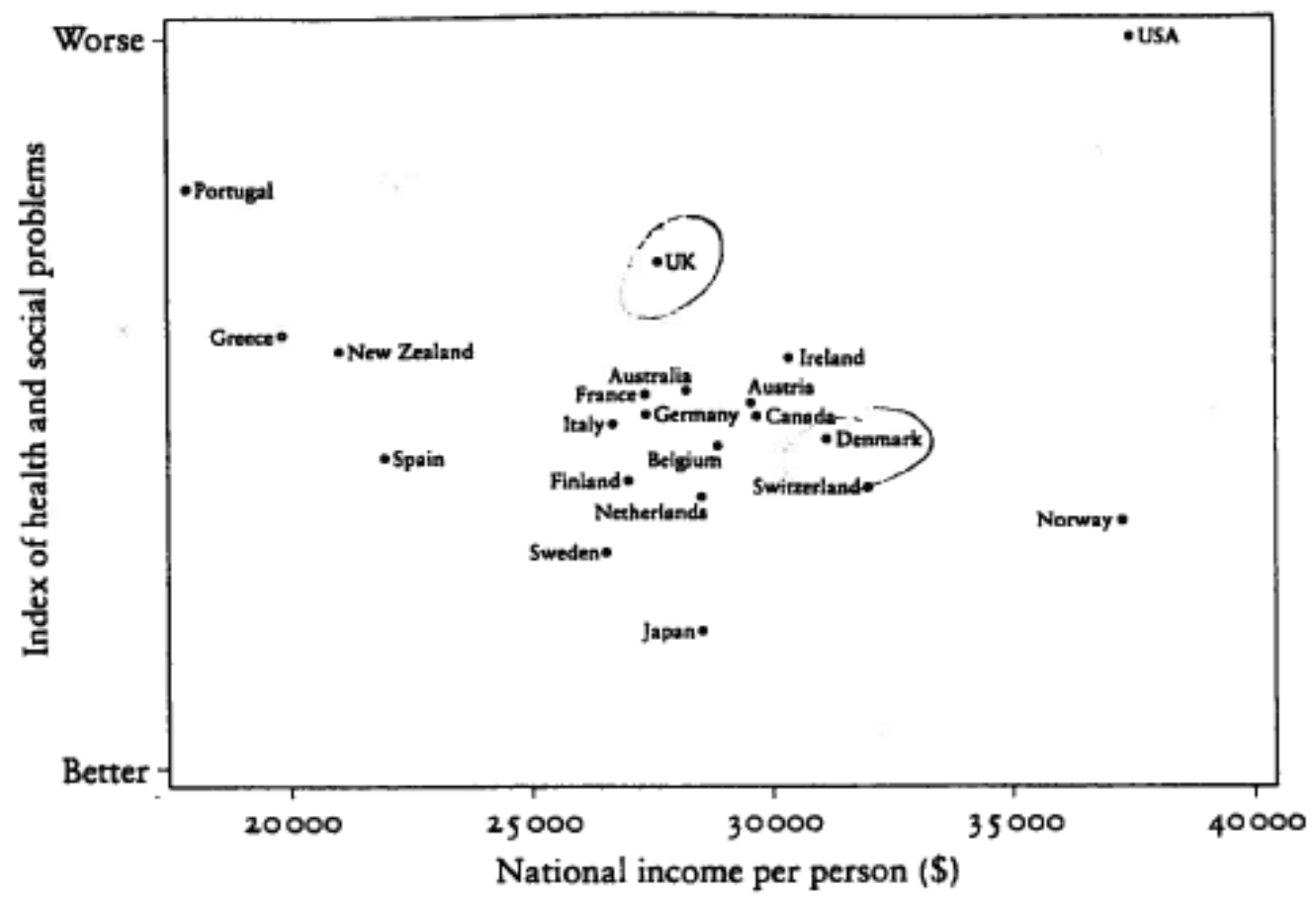

Figure 4: Health and social problems are closely related to inequality among rich countries

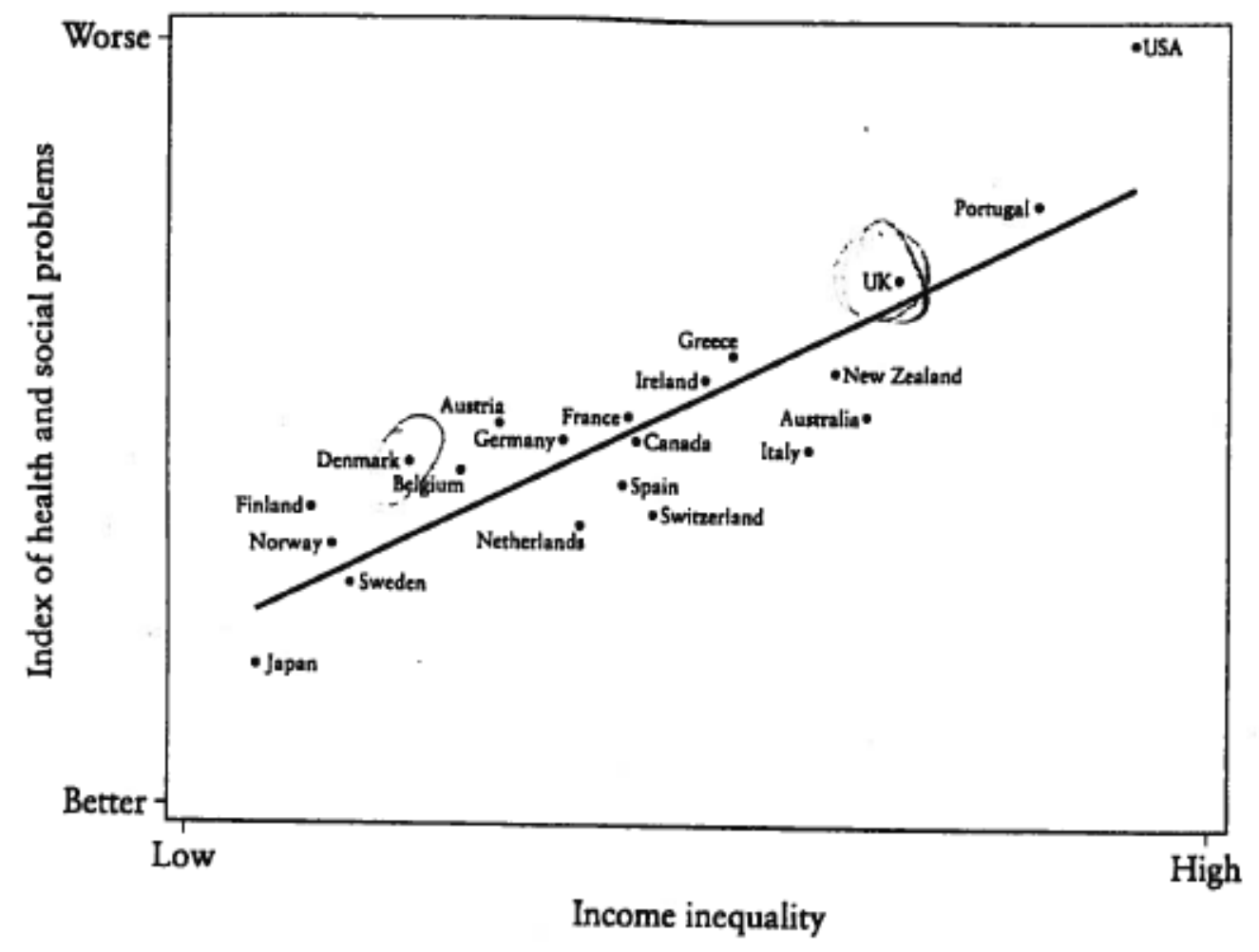




\subsection{SECOND QUESTION}

\section{Inequality: the reverberation on democracy}

Scholars of democracy firmly state that democracy, either in its ancient or modern version, never promised economic equality. ${ }^{18}$ Democracy promises political equality, ${ }^{19}$ and economic and social inequality is not expected to convert necessarily into political inequality. Though not necessarily, they however can.

How to define democracy nowadays, beyond regular elections and majority rule, in a world where citizens have many channels - associational, partisan, functional, territorial, collective, individual - to make their voices heard, and to participate in democratic processes $?^{20}$ The question is hard and we leave it to political scientists. Here I will lean upon the Dahlian concept of "polyarchic democracy" as the modern connotation of democratic government. Actually, I will go even beyond its five requirements for having political equality - namely, effective participation, voting equality, enlightened understanding, control of the agenda, and inclusion of adults ${ }^{21}$ focusing on subsequent requirements to be met in order to assess the quality of a democratic order. These further dimensions - so intertwined as to be often difficult to distinguish one from the other - are: rule of law,

18 "In its inception democracy was a project simply blind to economic inequality, regardless of how revolutionary it may have been politically. Morally based arguments for redistribution .......were marginal or ephemeral". Przeworski [2010] at p. 85. On the same position, Urbinati [2014], Ch. 1.

19 Dahl [2007] has beautiful passages on the principle of political equality.

20 Schmitter and Karl [1991]

21 "To the extent that any of the requirements is violated, the members will not be politically equal" Dahl [2000] at p. 38. Many variations of Dahl's scheme exist, with additional institutions, enlargements and refinements (the "thick" conception of democracy). All matters that go beyond our goal here and beyond our competences as well. 
participation, competition, vertical accountability, horizontal accountability, freedom, progressive implementation of greater political equality, and responsiveness. ${ }^{22}$ Whenever any of these eight qualitative dimensions is not fully realized, political inequality can arise even in a plain democracy because they are the basis for active citizenship.

A complete answer to the question "where does (economic and social) inequality impact on" is not given. The existing research in both the sociological and political science literature suggests to turn to the wide set of political (voting, campaigning...), civil (personal liberties) and socio-economic (associated with employment and private property....) rights, which require the formal equality of all citizens. Are the social costs of inequality implied by the unequal distribution of economic resources likely to affect any of those rights in a democratic setting? Can people be politically equal if they are socially unequal? In a greater or lesser extent, the answer is no, they cannot: differences in the "social power" of the citizens impact on their political equality. ${ }^{23}$

"The poor are in the grip of demagogues", Aristotle stated 2000 years ago. The increasing power of "the experts" coming from the technological progress tends to mute the voices of whole segments of the population (or to make them uniform), marginalizing them; the progressive concentration of the media in the hands of a few reduces the pluralism of information, and the emergence of a uniform voice lowers the quality of that information. Substantially uninformed people cannot fully exercise their political rights.

\footnotetext{
22 Diamond and Morlino [2004] at p. 21

${ }^{23}$ Among many, Held [2000], Dahl [2004], Young (2000), Stiglitz [2014]
} 
Low-educated people may more easily become victims of political manipulation and less interested in the functioning of the institutions of democracy, thus contributing to lowering the quality of democracy. The intergenerational persistence of disadvantages impedes-or makes very hard-any positive evolution for the lowest strata of society, and locks them in immobile stratification.

Similarly, the same disadvantaged segments of population can be particularly hit in their freedom by the incomplete implementation of essential social rights, such as the rights associated with employment. The same segments of population may have a deficit in political equality because of fewer opportunities to participate into political life, no chance whatsoever to influence either public debate or collective preferences, and no chance to control the governmental agenda. A deficit of effective participation arises if a part of the population is cut off from the modalities through which collective decisions are made, and this in turn determines what policies are actually adopted. Those same mechanisms do not affect the rich, who have many ways of protecting their status and interests. In the words of Bartels, "wealthier and better-educated citizens are more likely than the poor and less-educated to have clearly formulated and well-informed preferences. Inevitably, socioeconomic inequality percolates through the political realm: As Glaeser writes, "The rich can influence political outcomes through lobbying activities or membership in interest groups ... or bribing judges ... or making a mockery of popular democracy". ${ }^{24}$ As Bartels writes: "[wealthier are] significantly more likely to turn out to vote, to have direct contact with public

\footnotetext{
${ }^{24}$ Glaeser [2004] at p. 613
} 
officials, and to contribute money and energy to political campaigns." ${ }^{25}$ Even in societies characterized by formally democratic institutions, only affluent people and the elites have the "de facto" power, that one arising from an informal but nonetheless essential negotiation between political actors. ${ }^{26}$ Being able to shape political institutions through their current influence, the power of the uppermost tier of society, the elites, expands. As a result, political processes may in turn reinforce inequality and an alarming feedback loop might therefore take place. ${ }^{27}$ Thus, the political equality required by democracy is seriously damaged.

\section{SOME EMPIRICS}

Political theory has been suggesting at length that inequality should level automatically in a democratic setting-or slow down sensibly rather than surge-through the working of what is called the median voter mechanism. ${ }^{28}$ Besides some theoretical objections, ${ }^{29}$ this prediction has not been validated by facts: inequality surged in almost every democratic country. Thus, either

25 Bartels [2009] at p. 167

${ }^{26}$ Acemoglu and Robinson [2006] and [2008]

27 Bonica et al. [2013] specifically on the US; Przeworski [2012]

${ }^{28}$ This evergreen theorem was originally introduced in Duncan Black, "On the Rationale of Group Decision-making," Journal of Political Economy 56, no. 1 (1948), 23-34, and later developed in Kevin W. S. Roberts, "Voting over Income Tax Schedule," Journal of Public Economics 8, no. 3 (1977), 329-40, and Allan H. Meltzer and Scott F. Richard, "A Rational Theory of the Size of Government," Journal of Political Economy 89 (1981), 914-27. The most straightforward prediction of this famous theorem is that income redistribution becomes popular when the mean income is higher than the income of the median voter. According to this theory, in a democratic system the combination of taxes and transfers will be the one preferred by the voter who stays exactly in the middle of the distribution: the voter who has the median income. Since the empirical distributions in all advanced economies exhibit a median income lower than the mean, the higher the economic inequality the higher the combination of taxes and transfers in the preferences of the median voter should be. Thus, in a majoritarian democracy, it has to be expected that high inequality would gradually smooth out. 
re-distribution did not take place or it was insufficient to prevent inequality from surging. ${ }^{30}$ In both cases, political accountability emerges as the protagonist: the empirical negative correlation between inequality and redistribution reported ${ }^{31}$ is more easily readable as going from inequality to redistribution than viceversa. In fact, when inequality persists (or increases), "the electors" are not the poor or low- and middle-income citizens since, if they were, politicians would actively behave in ways intended to mitigate their unfavorable conditions and inequality would slow down. If this does not happen, it means that redistribution is avoided on purpose since wealth concentration has reverberated into politics. Thus, inequality impacts directly on institutions: there is an important piece of theoretical literature in political science that emphasizes that inequality will lead to different political institutions and in some case less democracy. ${ }^{32}$ However, empirical research is scant and only to some extent supports the view that unequal societies develop exploitative institutions. ${ }^{33}$

The sociological literature has pointed that economic inequality plays a role in a whole array of attitudes and behaviours (such as, for instance, social tolerance, trust, participation in voluntary associations...) considered important to the health of democracy. In this literature, the question whether people's own economic positions affect their attitudes toward democracy finds a clear positive answer: there is a strong negative effect of income inequality on support for democracy and ppeople are more likely to have

\footnotetext{
29 See Grossman and Helpman [2001]

30 Milanovic [2000]

31 Glaeser [2006], Fig. 34.3 at p. 631

32 Przeworski [2005], Benhabib and Przeworski [2006]

33 Savoia et al. [2010]
} 
favourable opinions of democracy if they are rich and live in a rich country. ${ }^{34}$ Just because the ills of society are perceived as potential threats to social cohesion and political structures, the social costs of inequality have recently drawn investigators' (a wide array of social scientists from different disciplines) attention with an eye on the political consequences. ${ }^{35}$

However, the empirical validation of the transmission of socioeconomic inequality into political inequality - i.e. the thesis that the stagnating economic fortunes of middle-class and poor people have diminished their influence on political agenda - is scant. Though we are convinced that money affects politics, political theorists argue that the role of nonpolitical resources in shaping political outcomes is not fully proved. ${ }^{36}$ They also agree that this might be due to the rudimentary state of the measurement of political influence, and to a quasi-impossibility of measuring democracy and its quality: "an appropriate democracy indicator is the Achille's heel of empirical analyses". ${ }^{37}$ Consequently, the relationship between economic inequality and the quality of democracy remains more a matter of speculation than of strict empirical observation.

Nonetheless, some results - particularly those by Bartels, Gilens and Kuhner - are noteworthy. For instance, there is evidence that the rich have great influence on the behavior of elected officials, while people in the bottom third of the income distribution seem to have no impact, and, in general, political leaders appear to react to what middle- and upper-income

${ }^{34}$ Andersen [2012]

35 Nolan et al. [2014], Salverda et al. [2014]

36 See Bartels [2008] and Przeworski [2010]

37 Gründler and Krieger [2015], at p. 39. They provide a full scrutiny of the indicators of democracy and their (very low) quality. Also Munck and Verkuilen [2002] 
citizens prefer. "Senators attached no weight at all to the views of constituents in the bottom third of the income distribution-the constituents whose economic interests were obviously most directly at stake. . . The views of middle-income constituents seem to have been only slightly more influential. . . . Senators' voting decisions were largely driven by the ideological predilections of their affluent constituents". ${ }^{38}$ Politicians appear also not to defend the interest of the many but the desires of the few depending on the relative strength of the trade union. ${ }^{39}$ Therefore, yes, responsiveness does exist but it is tilted towards the most affluent citizens. ${ }^{40}$ What do these affluent citizens prefer? There is some evidence for the US that the top fifth of the income distribution is socially more liberal but economically more conservative than others as a whole. Moreover, a (very) small sample of the American $1 \%$ seems very conservative with respect to important policies such as taxation, economic regulation, and especially social welfare programs. ${ }^{41}$

A fortiori among us economists, the quantitative literature on testing the quality of democracy is still very scant and mostly cross-country based because of the lack of suitable data. Among the findings there is that democracy by itself is not necessarily conducive to institutional quality without reference to the economic environment in terms of inequality Sunde et al. [2007]; that high-quality institutions like the rule of law, well-

38 Bartels [2008] at p. 265. Bartels himself reports the other studies - always on the US whose results go in the same direction of his. Limited to California only, Brunner et al. [2011] find opposite results.

${ }^{39}$ Torija [2013]

40 Gilens [2012] at p. 1.

41 Page et al. [2013] 
functioning regulation, low corruption, and other institutions that improve resource allocation have a positive effect on average satisfaction with democracy - Wagner et al. [2009]; that higher levels of income inequality powerfully depress political interest, the frequency of political discussion, and participation in elections (among all but the most affluent citizens!) Solt [2008]; that inequality lowers citizens' satisfaction and political discussion though stimulating the turnout - Maccagnan et al. [2014]. As far as I know, this is the only study focussing on a single country (the UK) rather than a set, in a long-run perspective.

\section{CONCLUDING REMARKS}

The majority of western democracies are now experiencing - though with different degrees and characteristics - high economic inequality, compression of low incomes, hollowing out of the "middles", and increasing concentration of wealth in few hands.

The role that inequality plays in rich and so-called well-established democracies prompts serious fears for the political health of their institutions. The substantial absence of growth takes to a deterioration of the economic and social conditions of the great many with a strengthening of social distance and social exclusion, and impoverishment of human and social capital. The "misappropriation" of the surplus by the few rich and the reverting of economic power into political power weaken the legitimacy of institutions, reduce trust and social consensus and subtly deteriorate the democratic context. Which outcome would result from this evolution goes beyond the goal of this paper. 


\section{REFERENCES}

Acemoglu D. and Robinson J.A. [2006], De Facto Political Power and Institutional Persistence, American Economic Review Papers\&Proceedings, 96:2, 325-330

Acemoglu D. and Robinson J.A. [2008], "Persistence of Power, Elites, and Institutions", American Economic Review 98:1, 267-293

Aghion P. and Williamson J. G. [1998], Growth, Inequality, and Globalization, Cambridge, Cambridge University Press

Alesina A. and Perotti R. [1996], "Income Distribution, Political Instability, and Investment," European Economic Review 40, No. 6, 1203-28

Alesina, A. and Rodrik, D. [1994], "Distributive Politics and Economic Growth", Quarterly Journal of Economics, CIX(2), 465-490

Andersen R. [2012], "Support for Democracy in Cross-National Perspective: the Detrimental Effect of Economic Inequality", Research in Social Stratification and Mobility, 30, 389-402

Banerjee A. V. and Duflo E. [2003], "Inequality and Growth: what Can Data Say", Journal of Economic Growth, 8, 267-299

Barone G., Mocetti S. [2014], Inequality and Trust: New Evidence from PanelData", Banca d'Italia, Temi di discussione No. 973

Barro Robert J. [2000], "Inequality and Growth in a Panel of Countries", Journal of Economic Growth, 5(1), 5-32

Bartels L. M. [2008], Unequal Democracy: The Political Economy of the New Gilded Age, Princeton University Press

Bartels L. M. [2009], "Economic Inequality and Political Representation", in L. Jacobs and D. King (eds.), The Unsustainable American State, Oxford University Press

Benabou R., “Unequal Societies”, [1996], NBER Working Paper No. 5583

Benhabib J. and Przeworski A., "The political Economy of Redistribution Under Democracy", Economic Theory, Vol. 29, 271-290

Berg A. G. and Ostry J. D. [2011], "Inequality and Unsustainable Growth: Two Sides of The Same Coin?" International Monetary Fund, Staff Discussion Note $11 / 08$ 
Bertola G. [1993], "Factor Shares and Savings in Endogenous Growth," American Economic Review 83, No. 5, 1184-98

Bonica A., McCarty N., Poole K.T. and Rosenthal H. [2013], "Why Hasn't Democracy Slowed Rising Inequality?" Journal of Economic Perspectives, Vol. 27(3), 103-124

Castelid A. and Domenech R. [2002], "Human Capital Inequality and Economic Growth: Some New Evidence", The Economic Journal, 112, March, 187-200

Cingano, F. [2014], "Trends in Income Inequality and its Impact on Economic Growth", OECD Social, Employment and Migration Working Papers, No. 163, OECD Publishing

Corak M. [2006], "Do Poor Children Become Poor Adults? Lessons from a Cross Country Comparison of Generational Earnings Mobility", IZA Discussion Paper No. 1993

Corak M. [2013], "Income Inequality, Equality of Opportunity, and Intergenerational Mobility", Journal of Economic Perspectives, Vol. 27(3), 79-102

Dahl R.A. (1998), On Democracy, Yale University Press

Dahl R. A. [2007], On Political Equality, Yale University Press

De Dominicis L., Florax R. J. G. M., deGroot H. L. F. [2008], “A Meta-Analysis On the Relationship Between Income Inequality and Economic Growth", Scottish Journal of Political Economy, Vol. 55 (5), 654-682

Diamond L. and Morlino L. [2004], "The Quality of Democracy: An Overview" Journal of Democracy 15, no. 4, 20-31

Gilens M. [2012], Affluence and Influence: Economic Inequality and Political Power in America, Princeton University Press and Russell-Sage Foundation

Glaeser E. L. [2006], "Inequality", in Barry R. Weingast and Donald A. Wittman (eds.), The Oxford Handbook of Political Economy, Oxford University Press, 62464

Gould E. D. and Hijzen A. [2016], "Growing Apart, Losing Trust? The Impact of Inequality on Social Capital", IMF Working Paper 16/176

Grigoli F. and Robles A. [2017], "Inequality Overhang”, IMF Working Paper 17/76 Grossman G. M. and Helpman E. [2001], Special Interest Politics, MIT Press

Gründler K. and Krieger T. (2015), "Democracy and Growth: Evidence of a New Measurement", CESIFO Working Paper No. 5647 
Held D. [2000], "Markets, private property and the possibility of democracy", in P. Wapner and E. J. Ruiz (eds.), Principled World Politics, Rowman and Littlefield, 151-165

Jäntti M., Bratsberg B., Røed K., Raaum O., Naylor R., Österbacka E., Björklund A. and Eriksson T. [2006], "American Exceptionalism in a New Light: A Comparison of Intergenerational Earnings Mobility in the Nordic Countries, the United Kingdom and the United States," IZA Discussion Paper No. 1938

Kuhner T. K. [204], Capitalism vs. Democracy: Money in Politics and the Free Market Constitution, Stanford University Press

Maccagnan A., Mantovani D. and Soci A. [2014], "Does Inequality Harm Democracy? An Empirical Investigation On the UK", Journal of Economic and Social Development Vol. 1, No.2

Milanovic B. [2000], "The Median-Voter Hypothesis, Income Inequality, and Income Redistribution: An Empirical Test with the Required Data", European Journal of Political Economy, Vo. 16, 367-410

Milanovic B. [2016], "Inequality: The Structural Aspects", Social Europe, February Munck G.L. and Verkuilen [2002], "Conceptualizing and Measuring Democracy Evaluating Alternative Indices", Comparative Political Studies, Vol. 35(1) 5-34

Nolan B., Salverda W., Checchi D., Marx I., McNight A., Toth I. G., van de Werfhorst H. [2014], Changing inequalities and societal impacts in rich countries: thirty countries' experience, Oxford University Press

Ostry J. D., Berg A. and Tsangarides C. G. [2014], "Redistribution, Inequality and Growth," International Monetary Fund Staff Discussion Note 14/02

Page B. I., Bartels L. M. And Seawright J. [2013], "Democracy And The Policy Preferences of Wealthy Americans", Perspective On Policy, Vol. 11/No. 1, 51-73

Perotti R. [1996], "Growth, Income Distribution and Democracy: What the Data Say," Journal of Economic Growth 1, June, 149-87

Persson T. and Tabellini G. [1994], "Is Inequality Harmful for Growth?," American Economic Review 84, No. 3, 600-21

Przeworski A. [2005], "Democracy as an equilibrium", Public Choice, 123, 253273

Przeworski A. [2010], Democracy and the Limits of Self-Government, Cambridge University Press 
Przeworski A. [2012], "Democracy, Redistribution and Equality", Brazilian Political Science Review, Vol.6(1), 11-36

Reeves R.V. [2017], Dream Hoarders, Washington, Brookings Institution Press

Rodrik D. [2014], "Good and Bad Inequality", Project Syndicate, December

Salverda W., Nolan B., Checchi D., Marx I., McNight A., Toth I. G., van de Werfhorst H. [2014], Changing inequalities in rich countries: analytical and comparative perspectives, Oxford University Press, 2014

Savoia A., Easaw J., Mckay A. [2010], "Inequality, Democracy, and Institutions: A Critical Review of Recent Research", World Development Vol.38, No.2, 142-154

Schmitter P. and Karl T. L. [1991], "What Democracy Is ... and Is Not," Journal of Democracy 2, 75-88

Shapiro T. M. [2017], Toxic Inequality, Basic Books

Solt F. [2008], "Economic Inequality and Democratic Political Engagement", American Journal of Political Science, Vol. 52, No. 1, 48-60

Stiglitz J.E. [2012], The price of inequality, Norton, 2012

Sunde U., Cervellati M., Fortunato P. [2007], "Are All Democracies Equally Good? The Role of Interactions Between Political Environment and Inequality for rule of law", IZA Discussion Paper No. 2984

Torija P. [2013], "Do Politicians Serve the One Percent? Evidence in OECD Countries", City Political Economy Research Center WP No.4

Urbinati N. [2014], Democracy Disfigured, Harvard University Press

Wagner A. F., Schneider F. and Halla M. [2009], "The Quality of Institutions and Satisfaction With Democracy in Western Europe - A Panel Analysis", European Journal of Political Economy, Vo. 25, 30-41

Wilkinson R. and Pickett K. [2009], The Spirit Level. Why Greater Equality Makes Societies Stronger, London, Allen Lane

Williams Joan C. [2017], White working Class: Overcoming Class Cluelessness in America, Harvard Business Review Press

Young I. M. [2000], Inclusion and Democracy, Oxford University Press 


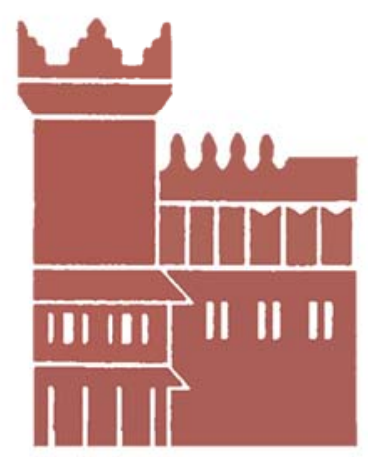

Alma Mater Studiorum - Università di Bologna DEPARTMENT OF ECONOMICS

Strada Maggiore 45

40125 Bologna - Italy

Tel. +39051 2092604

Fax +390512092664

http://www.dse.unibo.it 